\title{
THE STUDIES OF METAL CONTENT IN PRECIPITATION WATER IN LUBELSKIE AND LUBUSKIE VOIVODESHIPS IN 2013
}

\author{
Agnieszka Malec ${ }^{1}$, Gabriel Borowski² \\ 1 The Voivodeship Inspectorate of Environmental Protection in Lublin, Obywatelska St. 13, 20-092 Lublin, \\ Poland, e-mail: aga_malec@interia.pl \\ 2 Fundamentals of Technology Faculty, Lublin University of Technology, Nadbystrzycka St. 38, 20-618 Lublin, \\ Poland, e-mail: g.borowski@pollub.pl
}

Received: 2015.07.07

Accepted: 2015.08.31

Published: 2015.10.01

\begin{abstract}
This paper presents the results of the studies of metal content in precipitation water in 2013, recorded at measuring points within Lubelskie and Lubuskie Voivodeships. It provides a detailed description of the method of collecting and analysing water samples in respect of light- and heavy-metal determination. Based on the results, a general assessment was made of the condition of the environment in the areas in question. Also, the sources of pollution in wet precipitation, and the effects of their introduction into the environment, were determined. It was found that the main pollution elements of precipitation water were linked to anthropogenic sources. The study also established that precipitation water, especially in the sparsely industrialised Włodawa region in the Lubelskie Voivodeship, had generally low pollution levels. It was also noted that in 2013, due to low total precipitation, the environmental impact of metal content was lower than in the preceding years.
\end{abstract}

Keywords: precipitation, metals, chemism of precipitation.

\section{INTRODUCTION}

Monitoring the chemism of precipitation and assessing the depositing of pollutants into soils are among the tasks of the State Environmental Monitoring (PMŚ) air-quality monitoring subsystem, which has been in place since 1998 [Programme... 2012]. The purpose of this monitoring is to determine the distribution of pollutant content introduced into soil with wet precipitation at the national level, on a time-and-space basis. Systematic studies of the physical and chemical composition of precipitation and the concurrent observation and measurement of meteorological parameters provide information on the impact of substances deposited from the air - acidifying agents, biogenic substances and heavy metals on woodlands, soils and surface water, creating a basis for the assessment of the condition of the environment.

In 2013 the national measurement and control network consisted of 23 research stations studying the chemism of precipitation (weather stations of the Institute of Meteorology and Water Management - National Research Institute IMGW-PIB). These ensured the representativeness of the measurements for the assessment of the spatial distribution of pollutants. The network also included 162 precipitation stations, which made it possible to determine average precipitation totals for Poland (Figure 1).

Wet precipitation is continuously collected at precipitation stations, with the collected samples being determined quantitatively. The measurements and observations of the amount and type of precipitation, wind direction and speed, and air temperature, are conducted simultaneously with the collection of precipitation samples. Daily precipitation samples are collected at every station, and precipitation $\mathrm{pH}$, as well as precipitation amounts, are measured on an ongoing basis (after one precipitation day). Moreover, the following indicators are determined: electrical conductivity, chloride, sulphate, nitrite and nitrate, ammonia 


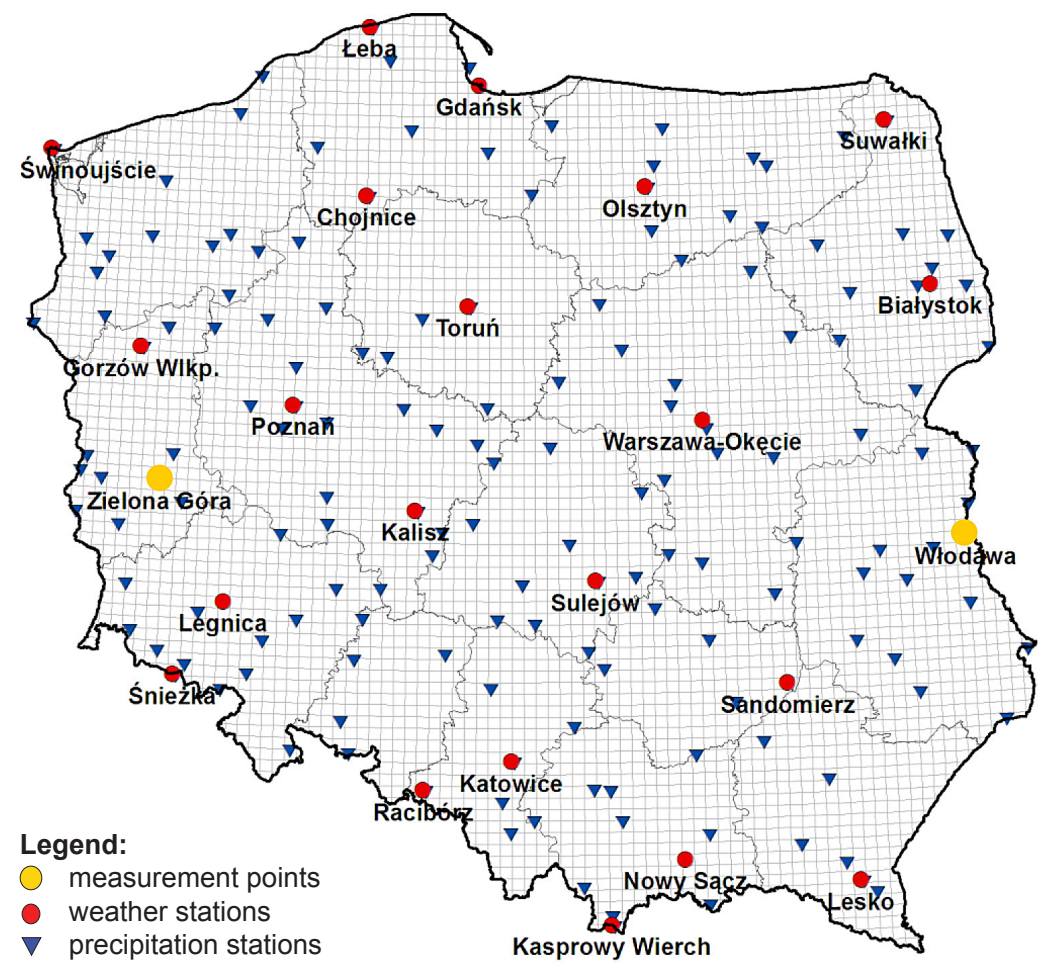

Figure 1. Precipitation-measurement stations in Poland

nitrogen, total nitrogen, total phosphorus, potassium, sodium, calcium, magnesium, zinc, copper, lead, cadmium, nickel and chromium. To determine total nitrogen concentration, total Kjeldahl nitrogen is specified.

The analysis of the physical and chemical composition of precipitation collected from the stations in a voivodeship is performed in licensed laboratories of voivodedeship inspectorates of environmental protection. Based on the measurement and analytical precipitation data collected from measurement stations, spatial-distribution maps were prepared of precipitation amounts and substance concentration in precipitation, and of the amount of their deposition [Raport... 2014; Stan środowiska... 2013].

The measurement and assessment of element content in precipitation are the subjects of numerous scientific papers. Czyzyk \& Rajmond [2011] analysed the results of 9-year studies of the chemical composition of precipitation on the eastern outskirts of Wrocław. The obtained results demonstrated a high content of some elements and compounds (nitrogen, sulphates and chlorides), which penetrate into soil and affect its fertility. Much-greater metal pollution of precipitation was observed when compared with the average amount recorded in Dolnośląskie Voivodeship. The high precipitation-pollution indicators in the studied areas resulted from the presence of many sources of air pollution - heat and power stations, industry, the public and residential sector, and the expanding road transport.

The studies of the selected constituents in precipitation performed in Szczecin and Międzyzdroje areas between 2008 and 2011 point to a substantial diversification in individual pollutant content, with no clear upward or downward trends in the studied indicators [Daniszewski 2012a, 2012b]. The so-called low-stack emission from local coal-fired boiler rooms and household heating stoves, in which coal combustion is ineffective, was found to be a major source of air and precipitation pollution.

The results of the studies of the chemism of precipitation in eastern France indicated an interrelation between the pollution content and the location of the sample collection - in rural or industrialised areas [Sanusi et al. 1996]. It was found that the concentration of metal ions was greater in urban areas, and precipitation acidity was lower in rural areas. This probably stems from the presence of calcium carbonate $\left(\mathrm{CaCO}_{3}\right)$ ash in the air, which neutralises the acidity of precipitation water.

The results of air-pollution studies conducted in the industrialised regions of China confirmed the impact of intensive economic development on the amount of pollution introduced into the environment, and especially of heavy metals [Wong et al. 2003]. 
Studies into 38 constituents of precipitation in the Arctic zone of northern Europe (Finland, Norway and Russia) demonstrated a very low element and compound content [Reimann et al. 1997]. The chemism of rainwater was monitored at eight research stations located within a nearly pristine area, at different distances from the defined sources of pollution. It was found that the element content in rainwater was mainly conditioned by anthropogenic factors [Moulia et al. 2005].

The objective of this paper is to present and compare the results of studies into metal content in precipitation in 2013 in two measurement points - Włodawa (the Lublin Voivodeship) and Zielona Góra (the Lubuskie Voivodeship). The sources of precipitation-water pollution were identified, and the general condition of the environment in the regions in question was evaluated.

\section{SAMPLE COLLECTION AND CHEMICAL ANALYSIS}

In this article we concentrate on analyses which were conducted in 2013. Samples of wet precipitation were collected at two selected research stations - in Włodawa (Lubelskie Voivodship) and in Zielona Góra (Lubuskie Voivodship).

The location of precipitation collectors and the detailed sample-collection procedure were in keeping with the requirements of the standard [PN-ISO 5667-8: 2003]. According to this standard, the collector's location should meet a series of requirements concerning, among other things, the terrain for placing the collector, the immediate vicinity of the collector, and the altitude of its location [Manual 1998].

To determine heavy-metal content in precipitation, samples were gathered using a separate collector (the sample for heavy-metal analysis is collected from a different collector from the samples for the remaining determinations), in which the funnel and bottles used for sample collection are made of glass, and the samples are preliminarily or post-collection acidified, using ca. $0.5 \%$ nitric acid. The process of collecting precipitation-water constituents for study purposes requires very strict rules of cleanness. The whole equipment (the funnel, precipitation containers, transport bottles, etc.) should be carefully cleaned. First, it was cleaned in deionised water (containers for heavy-metal testing samples - in $0.5 \% \mathrm{HNO}_{3}$, and then in deionised water). Subse- quently, the equipment was dried and stored in a dust-free atmosphere. In order to avoid touching surfaces in contact with the precipitation sample with bare hands, it is recommend to use disposable gloves (made of any plastic) [Manual for the GAW... 2004].

The precipitation-water sample-collection procedure is strictly defined [Manual Sampling and Analysis... 2004]. According to the procedure, precipitation samples are collected as weekly samples, which are analysed once a month after pouring them together. The surface of the sample must be free of any impurities. However, should such impurities appear, they must be removed, and a note about the impurity must be made in a sample-collection record. Samples must be stored in light-proof refrigerators at a temperature of up to $4^{\circ} \mathrm{C}$. Samples intended for determining heavymetal content should not be poured from the collector vessel into transport bottles. They should be sent in the same vessels in which they were collected and acidified on the spot at the station or in the laboratory, before conducting the analysis.

The analysed elements are calcium, magnesium, sodium, potassium, cadmium, lead, copper, nickel and zinc. The analysis is conducted on ICP-OES with the use of ultrasonic nebuliser. The water was collected in high-density polyethylene buckets. After the bucket was full, it was frozen and transported to the laboratory. When it was more than one bucketful, both were defrosted and joined together in one large container. Each sample is then filtered through $0.25 \mathrm{~mm}$, $0.22 \mu \mathrm{m}$ pore diameter cellulose membranes (millipore) in order to remove particulate matter. After that, for each $100 \mathrm{ml}$ of sample we add $0.5 \mathrm{ml}$ of $65 \%$ nitric acid.

\section{RESULTS AND DISCUSSION}

The results of the measurement of metal content in precipitation water in 2013 at measuring points within Lubelskie and Lubuskie Voivodeships are presented in Tables 1 and 2.

The light-metal content $(\mathrm{Na}, \mathrm{K}, \mathrm{Ca}, \mathrm{Mg})$ in precipitation at measurement points in the Lubelskie and Lubuskie Voivodeships were similar. In Włodawa, the observed cadmium content in precipitation water in June and July amounted to ca. 0.05 to $0,07 \mathrm{mg} \cdot \mathrm{dm}^{-3}$, and were much higher than in other months, which could have been caused by high temperatures and heavy rainfalls. The 
Table 1. The metal content in precipitation water in Włodawa in 2013

\begin{tabular}{|c|c|c|c|c|c|c|c|c|c|c|c|c|}
\hline \multirow{2}{*}{$\begin{array}{c}\text { Element } \\
{\left[\mathrm{mg} \cdot \mathrm{dm}^{-3}\right]}\end{array}$} & \multicolumn{12}{|c|}{ Month } \\
\hline & January & February & March & April & May & June & July & August & September & October & November & December \\
\hline $\mathrm{Ca}$ & 0.475 & 0.487 & 0.807 & 1.04 & 0.572 & 0.607 & 0.798 & 0.597 & 0.169 & 1.180 & 0.391 & 0.66 \\
\hline $\mathrm{Mg}$ & 0.054 & 0.097 & 0.122 & 0.096 & 0.140 & 0.061 & 0.094 & 0.089 & 0.024 & 0.105 & 0.091 & 0.11 \\
\hline $\mathrm{Na}$ & 0.285 & 0.401 & 0.381 & 0.203 & 0.082 & 0.093 & 0.186 & 0.188 & 0.087 & 0.359 & 0.174 & 0.61 \\
\hline K & 0.179 & 0.196 & 0.818 & 0.127 & 0.070 & 0.011 & 0.199 & 0.139 & 0.011 & 0.259 & 0.068 & 0.64 \\
\hline $\mathrm{Cd}$ & $<0.0002$ & $<0.0002$ & $<0.0002$ & $<0.0002$ & 0.0003 & 0.0560 & 0.0709 & $<0.0002$ & $<0.0002$ & $<0.0002$ & 0.0004 & 0.0004 \\
\hline $\mathrm{Pb}$ & $<0.001$ & 0.003 & $<0.001$ & $<0.001$ & $<0.001$ & $<0.001$ & $<0.001$ & 0.001 & $<0.001$ & $<0.001$ & 0.003 & 0.002 \\
\hline $\mathrm{Ni}$ & 0.001 & $<0.001$ & $<0.001$ & $<0.001$ & $<0.001$ & $<0.001$ & $<0.001$ & $<0.001$ & $<0.001$ & $<0.001$ & $<0.001$ & $<0.001$ \\
\hline $\mathrm{Cu}$ & 0.013 & 0.006 & 0.005 & 0.003 & 0.002 & 0.005 & 0.048 & 0.008 & 0.004 & 0.008 & 0.005 & 0.005 \\
\hline $\mathrm{Zn}$ & 0.051 & 0.054 & 0.056 & 0.025 & 0.015 & $<0.002$ & 0.026 & 0.025 & 0.014 & 0.051 & 0.029 & 0.041 \\
\hline
\end{tabular}

Table 2. The metal content in precipitation water in Zielona Góra in 2013

\begin{tabular}{|c|c|c|c|c|c|c|c|c|c|c|c|c|}
\hline \multirow{2}{*}{$\begin{array}{c}\text { Element } \\
{\left[\mathrm{mg} \cdot \mathrm{dm}^{-3}\right]}\end{array}$} & \multicolumn{12}{|c|}{ Month } \\
\hline & January & February & March & April & May & June & July & August & September & October & November & December \\
\hline $\mathrm{Ca}$ & 0.40 & 0.53 & 0.51 & 1.17 & 0.97 & 0.39 & 0.41 & 0.87 & 0.46 & 1.97 & 0.39 & 0.34 \\
\hline $\mathrm{Mg}$ & 0.05 & 0.08 & 0.05 & 0.12 & 0.09 & 0.05 & 0.05 & 0.09 & 0.06 & 0.14 & 0.05 & 0.06 \\
\hline $\mathrm{Na}$ & 0.34 & 0.59 & 0.37 & 0.46 & 0.20 & 0.09 & 0.09 & 0.27 & 0.26 & 0.71 & 0.43 & 0.59 \\
\hline K & 0.14 & 0.32 & 0.22 & 0.45 & 0.26 & 0.12 & 0.15 & 0.33 & 0.44 & 0.35 & 0.30 & 0.17 \\
\hline $\mathrm{Cd}$ & 0.0001 & 0.0002 & 0.0003 & 0.0002 & 0.0001 & 0.0001 & 0.0000 & 0.0000 & 0.0000 & 0.0001 & 0.0001 & 0.0001 \\
\hline $\mathrm{Pb}$ & 0.001 & 0.003 & 0.003 & 0.001 & 0.000 & 0.001 & 0.001 & 0.000 & 0.001 & 0.001 & 0.001 & 0.002 \\
\hline $\mathrm{Ni}$ & 0.000 & 0.020 & 0.000 & 0.001 & 0.000 & 0.000 & 0.001 & 0.002 & 0.000 & 0.001 & 0.000 & 0.001 \\
\hline $\mathrm{Cu}$ & 0.004 & 0.005 & 0.006 & 0.007 & 0.004 & 0.009 & 0.014 & 0.009 & 0.007 & 0.009 & 0.008 & 0.008 \\
\hline $\mathrm{Zn}$ & 0.005 & 0.030 & 0.013 & 0.046 & 0.026 & 0.073 & 0.043 & 0.053 & 0.054 & 0.022 & 0.024 & 0.004 \\
\hline
\end{tabular}

highest lead content at both measurement points were recorded in February, and amounted to $0.003 \mathrm{mg} \cdot \mathrm{dm}^{-3}$. The high amount of air pollution from boiler rooms and central-heating stoves in residential buildings might be the reason for the higher lead content in winter. In Zielona Góra the high nickel content in precipitation water was recorded in February. It amounted to $0.02 \mathrm{mg} \cdot \mathrm{dm}^{-3}$, which was probably due to the higher pollution emissions in industrialised areas located near the measurement point, and from building-heating equipment used in winter. Lower copper and zinc content were recorded in the Włodawa region throughout the larger part of the year, which stemmed from low industrialisation of the region. The higher content of heavy metals in precipitation water in Zielona Góra was the result of higher pollution emissions into the air, mainly by industrial facilities located near this measurement station. Nevertheless, the heavy-metal content in precipitation water collected from both measurement stations was much lower than the maximum limit stipulated by law [Journal of Laws of 2014, item 1482], which proved the relatively good condition of the environment in both locations in question.

A similar interrelation between the amount of dust and gaseous pollutants in the atmosphere and the chemism of precipitation water was recorded by other researchers [Smoron et al. 2006; Walna, Siepak 1995]. Of note was also the impact of heavy rainfalls, characteristic of the Podhale regions, on the increase in the concentration of most mineral constituents in precipitation water.

Based on the results of 15-year monitoring studies of the chemism of precipitation and the depositing of pollutants into soils, conducted on an ongoing basis in the Lubelskie Voivodeship between 1999 and 2013, it was found that the depositing of the majority of constituents introduced with precipitation was lower in 2013 when compared to the previous-years' average [Report... 2013]. Also, the annual average amount of precipitation was lower by $11.8 \%$, which confirms that 2013 was drier than the preceding years. Therefore, due to lower precipitation in the 
period in question, the environmental impact of the metal content might have been smaller than the previous-years' average.

\section{CONCLUSIONS}

Monitoring the chemism of precipitation and assessing the depositing of pollutants into soils currently constitute the most comprehensive source of information on the quality of precipitation water and the spatial distribution of the wet depositing of pollutants. The results of the measurements of the metal content in precipitation water at the selected stations in the Lubelskie and Lubuskie Voivodeships in 2013 revealed significant similarities, especially when it came to the light-metal content. The differences in the study results concerned mainly the heavy-metal content (cadmium, lead and nickel) in the winter and summer months. It was found that the pollution of precipitation water was mainly caused by anthropogenic sources. In the period in question, only a small amount of metal pollution was introduced into the environment with precipitation. This was especially true for the sparsely industrialised Włodawa region. However, it should be noted that in 2013 we observed much less total precipitation than in the years before, which could have contributed to the lower environmental impact of the metal content.

\section{REFERENCES}

1. Czyżyk F., Rajmund A. 2011. Ilości niektórych pierwiastków wnoszone do gleby z opadami atmosferycznymi w rejonie Wrocławia w latach 2002-2010. Inżynieria Ekologiczna, 27, 5-12.

2. Daniszewski P. 2012a. The dynamics of concentration of selected chemical components of rainfalls in the Szczecin. International Letters of Chemistry, Physics and Astronomy, 5, 80-87.

3. Daniszewski P. 2012b. The dynamics of concentration of selected chemical components of rainfalls in the Miedzyzdroje. International Letters of Chemistry, Physics and Astronomy, 5, 72-79.

4. Dz.U. 2014, poz. 1482. Rozporządzenie Ministra Środowiska z dnia 22 października 2014 r. w sprawie sposobu klasyfikacji stanu jednolitych części wód powierzchniowych oraz środowiskowych norm jakości dla substancji priorytetowych.

5. Manual 1998. Manual for Integrated Monitoring International Co-operative Programme on Integrated Monitoring of Air pollution Effects on Ecosystems, ICP IM Programme Centre Helsinki.

6. Manual for the GAW Precipitation Chemistry Programme 2004: Guidelines, Data Quality Objectives and Standard Operating Procedures, No 160.

7. Manual Sampling and Analysis of Deposition 2004: Part VI, International Co-operative Programme on Integrated Monitoring of Air pollution Effects on Forest.

8. Moulia P.C., Mohanb S.V., Reddy S.J. 2005. Rainwater chemistry at a regional representative urban site: influence of terrestrial sources on ionic composition. Atmospheric Environment, 39, 999-1008.

9. PN-ISO 5667-8: 2003. Jakość wody, pobieranie próbek, część 8: Wytyczne dotyczące pobierania opadu mokrego.

10. Program Państwowego Monitoringu Środowiska na lata 2013-2015. Główny Inspektor Ochrony Środowiska, Warszawa 2012.

11. Raport o stanie środowiska województwa lubelskiego w 2013 roku. Wojewódzki Inspektorat Ochrony Środowiska, Lublin 2014.

12. Reimann C., De Caritat P., Halleraker J.H., Volden T., Ayras M., Niskavaara H., Chekushins V.A., Pavlovs V.A. 1997. Rainwater composition in eight arctic catchments in Northern Europe (Finland, Norway and Russia). Atmospheric Environment, 31(2), 159-170,

13. Sanusi A., Wortham H., Millet M., Mirabel P. 1996. Chemical composition of rainwater in Eastern France. Atmospheric Environment, 30(1), 59-71.

14. Smoroń S, Twardy S., Janota D. 2006. Stężenia i ładunki niektórych składników mineralnych w wodach opadowych rejonu Podhala w latach 20022004. Woda-Środowisko-Obszary Wiejskie, t. 6, z. 2(18), 335-345.

15. Stan środowiska w województwie lubuskim w latach 2011-2012. Wojewódzki Inspektorat Ochrony Środowiska, Zielona Góra 2013.

16. Walna B., Siepak J. 1995. Chemizm wód opadowych w Stacji Ekologicznej UAM w Jeziorach w Wielkopolskim Parku Narodowym. Ekologia i Technika, 3(6), 24-29.

17. Wonga C.S.C., Lia X.D., Zhangb G., Qib S.H., Peng X.Z. 2003. Atmospheric deposition of heavy metals in the Pearl River Delta, China. Atmospheric Environment, 37, 767-776. 